\title{
Physiological responses of beet plants irrigated with saline water and silicon application
}

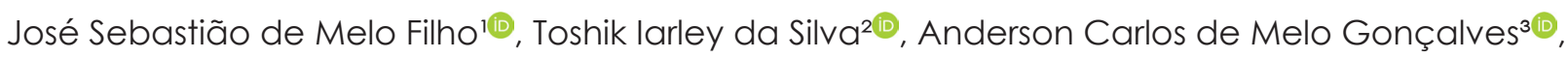 \\ Leonardo Vieira de Sousa ${ }^{\circledR}$, Mario Leno Martins Véras ${ }^{2 *}{ }^{\circledR}$, Thiago Jardelino Dias ${ }^{10}$ \\ 'Federal University of Paraíba, Areia, Brazil \\ ${ }^{2}$ Federal University of Viçosa, Viçosa, Brazil \\ ${ }^{3}$ Federal University of Roraima, Boa Vista, Brazil \\ *Corresponding author, e-mail: mario.veras1992@gmail.com
}

\begin{abstract}
Although not considered an essential element, silicon can be used to increase crop productivity, especially under stress conditions. In this sense, the objective was to evaluate the gas exchange of beet plants irrigated with saline water depending on the application of silicon. The experiment was conducted in a randomized block design, in a $5 \times 5$ factorial, referring to five levels of electrical conductivity of irrigation water (ECW): $\left(0.5 ; 1.3 ; 3.25 ; 5.2\right.$ and $\left.6.0 \mathrm{dS} \mathrm{m}^{-1}\right)$ and five doses of silicon $\left(0.00 ; 2.64 ; 9.08 ; 15.52\right.$ and $\left.18.16 \mathrm{~mL} \mathrm{~L}^{-1}\right)$, with six beet plants as an experimental unit. The effect of treatments on beet culture was evaluated at 30 and 60 days after irrigation with saline water from measurements of internal carbon concentration, stomatal conductance, net photosynthesis rate, instantaneous water use efficiency and instantaneous carboxylation efficiency using the LCpro+Sistem infrared gas analyzer (IRGA). Irrigation with saline water reduced the gas exchange of beet plants at 60 days after irrigation, but at 30 days after irrigation, the use of saline water increased stomatal conductance, transpiration rate and internal carbon concentration. The application of silicon decreased stomatal conductance, internal carbon concentration and efficiency in the use of water, but increased the rate of net photosynthesis, the rate of transpiration and instantaneous efficiency of carboxylation at 30 and 60 days after irrigation.
\end{abstract}

Keywords: Beta vulgaris L., saline stress, photosynthesis, potassium silicate, gas exchange

\section{Introduction}

One of the main obstacles to agricultural production in the Brazilian northeastern region is low rainfall. In addition, most waters have a high salt concentration, corresponding to electrical conductivity values above $4 \mathrm{dS}^{-1}$, affecting water absorption and causing toxic effects (Munns \& Tester 2008; Taiz et al., 2017), hindering several physiological and biochemical processes, and consequently, resulting in less growth and development of cultures (Sá et al., 2013; Sá et al., 2015; Oliveira et al., 2017).

Several studies have shown that salinity in irrigation water causes several phytotoxic effects on plants, including loss of photosynthetic activity, attributed to stomatal and non-stomatal limitations (Kusvuran, 2012; Freire et al., 2014; Sousa et al., 2016).

Alternatives to mitigate or reduce the harmful effects of salt stress, such as attenuating substances, such as silicon ( $\mathrm{Si}$ ), are fundamental, and although silicon is not considered an essential element for plants, it has beneficial effects on the development of plants (Guntzer et al., 2012). In recent years, studies have shown that Si can alleviate the effects of abiotic stresses, such as salinity and drought (Ali et al., 2012; Zhu \& Gong, 2014; Sahebi et al., 2016). In addition, its application can provide greater growth of many plant species (sunflower, cotton and castor) under saline conditions (Silva et al., 2009; Ferraz et al., 2014; Ferraz et al., 2015).

In crops such as wheat, sorghum, tomatoes and corn under stress conditions, the application of silicon promoted greater leaf area, chlorophyll content and improved the structure of chloroplasts, which provided an increase in photosynthetic activity (Tahir et al., 2012; Bae et al., 2012; Yin et al., 2013; Haghighi \& Pessarakli, 2013; Rohanipoor et al., 2013). However, for beet studies involving the application of possible attenuators for salt stress are scarce.

As a result, studies to assess the potential of $\mathrm{Si}$ as an alternative to reduce the harmful effects of saline waters on beet cultivation are extremely relevant. In this sense, the objective was to evaluate the physiological responses of beet irrigated with saline water depending on the application of silicon. 


\section{Materials and Methods}

The experiment was conducted from August to October 2017 in a greenhouse located in the Fruit sector, belonging to the Federal University of Paraíba, in the city of Areia-PB, Brazil, located at the geographical coordinates 6 61'47 "and 7 ${ }^{\circ} 02^{\prime} 04^{\prime \prime}$ south latitude and $35^{\circ} 34^{\prime} 13^{\prime \prime}$ and $35^{\circ} 48^{\prime} 28^{\prime \prime}$ west longitude of the Greenwich meridian, with an elevation of $575 \mathrm{~m}$ above sea level.

During the conduction of the experiment, climatic data (Figure 1) were recorded daily with an HT-600 Instruthermr ${ }^{\oplus}$ digital thermohygrometer, installed inside the experimental area, at plant height. The average climatic values of temperature were close to the range considered ideal $\left(15\right.$ to $\left.25^{\circ} \mathrm{C}\right)$ during the culture cycle, according to Filgueira (2008).
Beet seedlings of cv. Maravilha were produced in trays and planted in pots $22 \mathrm{~cm}$ in diameter, $16 \mathrm{~cm}$ in diameter and $18 \mathrm{~cm}$ in height, with a volumetric capacity of $8 \mathrm{dm}^{3}$, and with circular holes $1 \mathrm{~cm}$ in diameter on its underside, in order to allow better aeration of the roots and percolation of excess water.

The pots were filled with horizon A soil collected at a depth of $0-20 \mathrm{~cm}$, classified as Planosol Haplic Eutrophic (Embrapa, 2014), the chemical and physical characteristics (Table 1) were analyzed according to Embrapa's methodology (2014), respectively. The soil was previously air-dried and duly homogenized, being placed in the canvas (tulle fabric) and $200 \mathrm{~g}$ gravel pots, to prevent soil from leaving the pots through their lower holes.

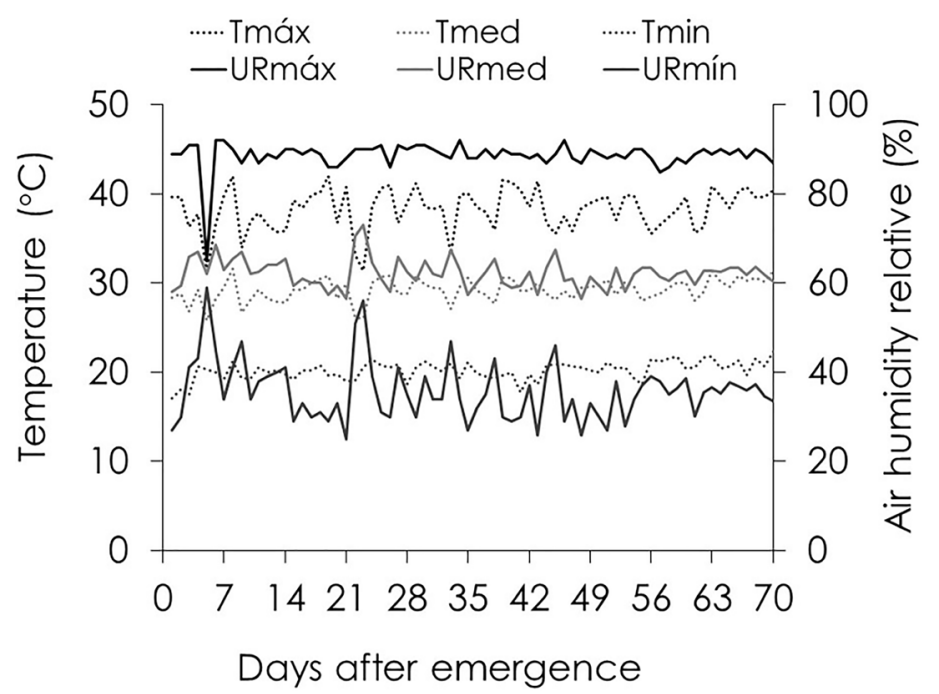

Figure 1. Graphical representation of the relative humidity and temperature in the period of conduction of the experiment. Maximum (Tmax), average (Tmed) and minimum (Tmin) air temperatures in ${ }^{\circ} \mathrm{C}$; maximum relative humidity (URmax), average (URmed) and minimum (URmin) in \%.

Table 1. Chemical and physical characteristics of the soil used in the experiment

\begin{tabular}{|c|c|c|c|}
\hline Chemical attributes & & Physical attributes & \\
\hline $\mathrm{pH}$ & 6.26 & Ds & 1.38 \\
\hline$P\left(m g ~ d m^{-3}\right)$ & 11.35 & Dp & 2.67 \\
\hline $\mathrm{K}^{+}\left(\mathrm{mg} \mathrm{dm}{ }^{-3}\right)$ & 40 & PT & 0.48 \\
\hline $\mathrm{Na}^{+}\left(\mathrm{cmol} \mathrm{dm}^{-3}\right)$ & 0.22 & CC & 78 \\
\hline $\mathrm{H}+\mathrm{Al}\left(\mathrm{cmol} \mathrm{dm}^{-3}\right)$ & 1.82 & $\operatorname{PMP}\left(\mathrm{g} \mathrm{g}^{-1}\right)$ & 43 \\
\hline $\mathrm{Al}^{+3}\left(\mathrm{cmol} \mathrm{dm}^{-3}\right)$ & 0 & Sand $\left(\mathrm{g} \mathrm{kg}^{-1}\right)$ & 756.9 \\
\hline $\mathrm{Ca}^{+2}\left(\mathrm{cmol} \mathrm{dm}^{-3}\right)$ & 3 & Silt $\left(g_{k g}^{-1}\right)$ & 59.1 \\
\hline $\mathrm{Mg}\left(\mathrm{cmol} \mathrm{dm}^{-3}\right)$ & 1.9 & Clay $\left(\mathrm{g} \mathrm{kg}^{-1}\right)$ & 184 \\
\hline $\mathrm{SB}\left(\mathrm{cmol} \mathrm{dm}^{-3}\right)$ & 5.22 & - & - \\
\hline $\operatorname{CEC}\left(\mathrm{cmol}_{\mathrm{c}} \mathrm{dm}^{-3}\right)$ & 7.03 & - & - \\
\hline$\vee(\%)$ & 74.34 & - & - \\
\hline$M(\%)$ & 0 & - & - \\
\hline$O M\left(\mathrm{~g} \mathrm{Kg}^{-1}\right)$ & 17.53 & Textural classification & Sandy loam \\
\hline
\end{tabular}


The beet plants were irrigated daily, with sufficient water volume to raise the soil moisture to the level of field capacity and recording all applied volume. These irrigations were carried out with non-saline waters ( $E C W=$ $0.5 \mathrm{dS} \mathrm{m}^{-1}$ ) and saline waters ( $E C W=1.3 ; 3.25 ; 5.2$ and 6.0 $\mathrm{dS} \mathrm{m}^{-1}$ ), and every 15 days, soil washes were performed with each type of water used. The different $\mathrm{ECW}$ were obtained by using the salts of $\mathrm{NaCl}, \mathrm{CaCl}_{2} \cdot 2 \mathrm{H}_{2} \mathrm{O}$ and $\mathrm{MgCl}_{2} \cdot 6 \mathrm{H}_{2} \mathrm{O}$, in the proportion of 7:2:1 (Medeiros, 1992) as shown in Table 2. Irrigation with water sources of different salinities was started 10 days after emergence.

Table 2. Chemical characteristics of the waters used in the experiment

\begin{tabular}{|c|c|c|c|c|c|}
\hline \multirow[b]{2}{*}{ Attributes } & \multicolumn{5}{|c|}{ Water electric conductivity (dS $\mathrm{m}^{-1}$ ) } \\
\hline & 0.50 & 1.30 & 3.25 & 5.20 & 6.00 \\
\hline & \multicolumn{5}{|c|}{ Values } \\
\hline $\mathrm{pH}$ & 7.00 & 7.50 & 7.40 & 7.30 & 7.40 \\
\hline $\mathrm{SO}^{-2}$ & 3.22 & 3.70 & 3.67 & 3.35 & 3.90 \\
\hline $\mathrm{Mg}^{2+}$ & 1.33 & 1.78 & 1.93 & 2.03 & 2.98 \\
\hline $\mathrm{Na}^{+}$ & 1.70 & 5.92 & 12.57 & 20.5 & 24.20 \\
\hline $\mathrm{K}^{+}$ & 0.20 & 0.21 & 0.20 & 0.20 & 0.21 \\
\hline $\mathrm{Ca}^{2+}$ & 0.73 & 1.58 & 1.78 & 1.88 & 2.53 \\
\hline $\mathrm{CO}_{3}^{-2}$ & 0.00 & 0.00 & 0.00 & 0.00 & 0.00 \\
\hline $\mathrm{HCO}_{3}^{3}-$ & 2.75 & 3.50 & 4.00 & 4.25 & 4.25 \\
\hline $\mathrm{Cl}^{-}$ & 3.40 & 10.90 & 30.40 & 48.90 & 58.15 \\
\hline SAR $\left(\mathrm{mmol} \mathrm{L}^{-1}\right)$ 0.5 & 1.28 & 1.87 & 2.60 & 3.23 & 2.96 \\
\hline Classification & $\mathrm{C} 2 \mathrm{~S} 1$ & C3S3 & C4S4 & C4S4 & C4S4 \\
\hline
\end{tabular}

The silicon was applied in the form of potassium silicate $\left(\mathrm{K}_{2} \mathrm{SiO}_{3}\right)$, liquid, with $12 \% \mathrm{Si}$ and $15 \% \mathrm{~K}_{2} \mathrm{O}$. The doses of $\mathrm{Si}$ from the treatments were applied through a hand sprayer. The application was made weekly, totaling 7 applications during the development of sweet potato. The doses of (Si) were diluted in distilled water, with 50 $\mathrm{ml}$ of this solution applied to each plant. Because the source of silicon (potassium silicate) contains $15 \% \mathrm{~K}_{2} \mathrm{O}$, compensation was performed via fertigation for each treatment, subtracting the amount of $\mathrm{K}$ applied via foliar in $\mathrm{KCl}$ top dressing, thus maintaining the homogenization of this element, regardless of the treatment.

The planting and covering fertilization were carried out with 40, 180 and $90 \mathrm{~kg} \mathrm{ha}^{-1}$ of NPK, respectively, with urea, simple superphosphate and potassium chloride, according to the chemical analysis of the soil and fertilization recommendation for the State of Pernambuco (IPA, 2008). During the conduct of the experiment, pest and weed control was performed based on manual picking and weeding of invasive plants.

The effect of treatments on beet culture was evaluated at 30 and 60 days after irrigation with saline water from measurements of the internal carbon concentration ( $\mathrm{Ci}-\mu \mathrm{mol}$ mol air ${ }^{-1}$ ), stomatal conductance (gs - $\mathrm{mol} \mathrm{H}_{2} \mathrm{O} \mathrm{m}^{-2} \mathrm{~s}^{-1}$ ), transpiration ( $\mathrm{E}-\mathrm{mmol} \mathrm{H}_{2} \mathrm{O} \mathrm{m}^{-2} \mathrm{~s}^{-1}$ ), net photosynthesis rate $\left(\mathrm{A}-\mu \mathrm{mol} \mathrm{m} \mathrm{m}^{-2} \mathrm{~s}^{-1}\right)$, water use efficiency (WUE - A/E), instantaneous water use efficiency (iWUE - A/E) calculated by relating it to net photosynthesis with transpiration $\left[\left(\mu \mathrm{mol} \mathrm{m} \mathrm{m}^{-2} \mathrm{~s}^{-1}\right) /\left(\mathrm{mmol} \mathrm{H}_{2} \mathrm{O} \mathrm{m}^{-2} \mathrm{~s}^{-1}\right)\right]$ and instantaneous carboxylation efficiency (iCE - A/Ci) [ ( $\mu \mathrm{mol}$ $\left.\mathrm{m}^{-2} \mathrm{~s}^{-1}\right) /\left(\mu \mathrm{mol} \mathrm{mol}\right.$ air $\left.\left.{ }^{-1}\right)\right]$ from the relationship between net photosynthesis and internal carbon concentration using the LCpro+Sistem infrared gas analyzer (IRGA).

The experimental design was in randomized blocks, in a $5 \times 5$ factorial, referring to five levels of electrical conductivity of the irrigation water (ECW): (0.5;

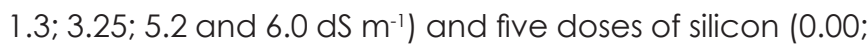
$2.64 ; 9.08 ; 15.52$ and $\left.18.16 \mathrm{~mL} \mathrm{~L}^{-1}\right)$, combined according to the experimental matrix Central Compound of Box (Mateus et al., 2001), totaling ten treatments, with four replications, with six beet plants as an experimental unit. Statistical analyzes were performed with their confidence interval to compare the two evaluation dates using the statistical program R (R Core Team, 2018).

\section{Results and Discussion}

Stomatal conductance showed a difference in all ECW in relation to the evaluation periods. At $30 \mathrm{DAl}$, there was an average increase in stomatal conductance as the ECW increased, which may be related to the plant's effort to stand out from stress. However, at 60 DAl, it is clear that there was a drastic reduction in stomatal conductance compared to $30 \mathrm{DAl}$. Either this can be linked to the excess of salts in the root zone or even to the age of the plant, considering that there is no significant variation between ECW (Figure 2A).

The same behavior was observed for sweating, which is related to stomatal opening (gs), because as 
the stomata close, consequently, there is a decrease in the transpiratory rate (Figure $2 \mathrm{C}$ ). This reduction can be attributed mainly to the lower water absorption by beet plants, thus an alternative to reduce the rate of transpiration is the closure of stomata. However, the
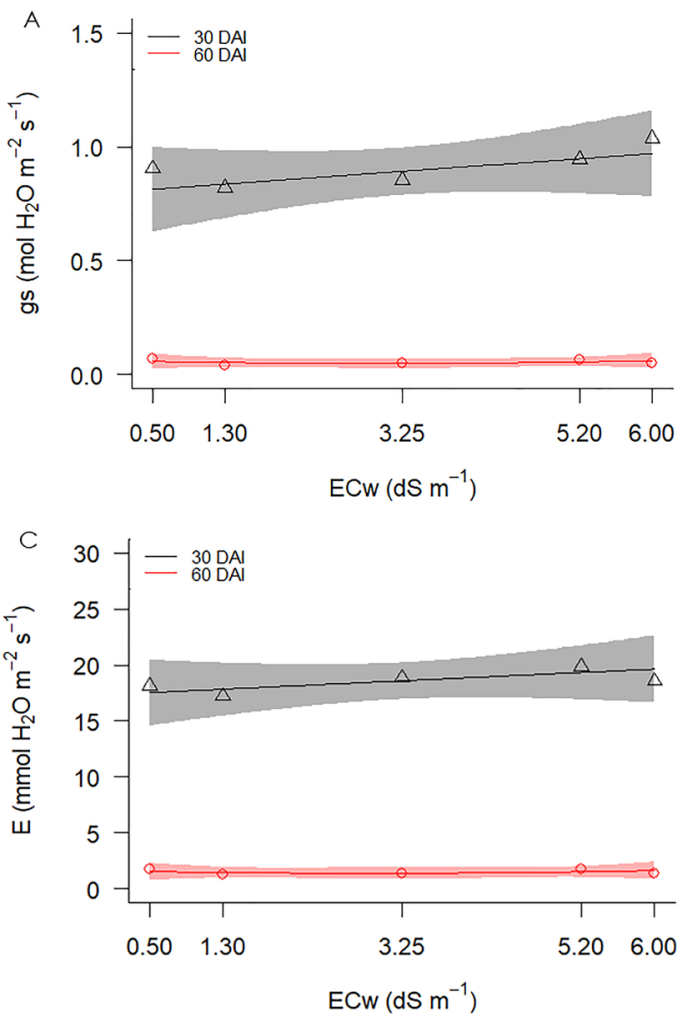

Figure 2. Stomatal conductance (gs - A), net photosynthesis ( $-B$ ), transpiration ( $\mathrm{E}-\mathrm{C}$ ) and internal carbon concentration ( $\mathrm{Ci}$ - D) of beet plants at 30 and 60 days after the beginning (DAI) of irrigation with saline water.

As for the rate of net photosynthesis, it was observed that there were differences between the two evaluation periods in the evaluated ECW. At $60 \mathrm{DAl}$, the net photosynthetic rate was lower (Figure 2B). For the internal $\mathrm{CO}_{2}$ concentration (Figure 2D) there was a difference between the evaluation periods, however, the lowest Ci was at 30 DAl. This behavior may be linked to the fact that at $60 \mathrm{DAl}$ there is a higher concentration of internal carbon in the intercellular spaces, and that this is not being used for photosynthetic processes.

It was observed that the stomatal conductance of the beet plants, at $30 \mathrm{DAl}$, decreased as the dose of $\mathrm{Si}$ increased, at $60 \mathrm{DAl}$ it was observed that there was an increase up to the dose of $9.08 \mathrm{~mL} \mathrm{~L}^{-1}$, decreasing in subsequent doses (Figure 3A). These results corroborate those obtained by Ferraz et al. (2014) in cotton culture, when observing that the increase in Si doses reduced stomatal conductance, obtaining the highest conductances in plants that did not receive Si. The same behavior was observed for transpiration (E), which decreased as the Si doses increased to 30 DAl. At 60 closure of stomata also reduces the photosynthetic rate due to the lower availability of $\mathrm{CO}_{2}$ (Pereira et al., 2013; Ghobadi et al., 2013; Cerqueira et al., 2015), causing the reduction in the growth and development of the plants, corroborating the data obtained in the present work.
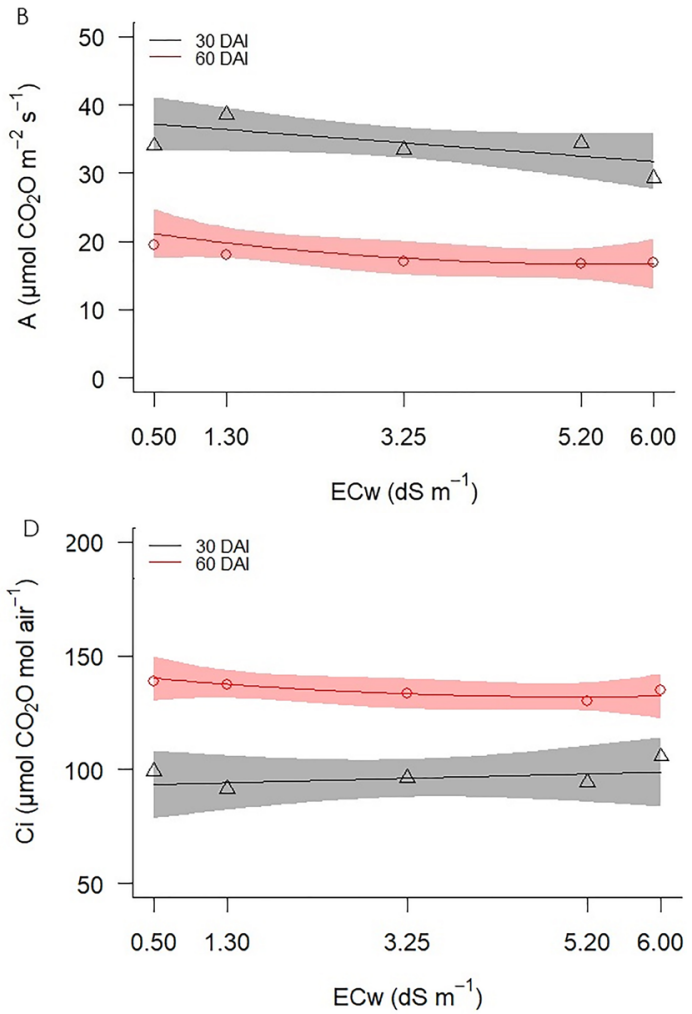

DAl there was an increase up to the dose of $9.08 \mathrm{~mL} \mathrm{~L}^{-1}$, decreasing in subsequent doses (Figure $3 \mathrm{C}$ ). The results obtained in the present study corroborate those observed by Jesus et al. (2018) in arugula, when they found that the application of silicon increased the rate of transpiration.

The reduction in stomatal conductance and transpiration can be attributed to the accumulation of $\mathrm{Si}$ in the epidermal cells and, in the stomatal walls, being in the form of $\mathrm{H}_{4} \mathrm{SiO}_{4}$ (monosilicic acid). Thus, with the loss of water, the monomeric form of Si becomes the polymeric form, that is, Si begins to form heavier chains of polysilicic acid. Subsequently, there is a reduction in the flexibility of the stomatal walls and the tendency is to be closed, reducing stomatal conductance and transpiration (Luz ef al., 2006) as observed in the present study.

At $30 \mathrm{DAl}$, the rate of net photosynthesis showed a weighted decrease with the dose of $9.08 \mathrm{~mL} \mathrm{~L}^{-1}$ of $\mathrm{Si}$, obtaining in this the lowest rate of net photosynthesis (30 $\mu \mathrm{mol} \mathrm{m}^{-2} \mathrm{~s}^{-1}$ ) and the highest net photosynthetic rate (39 $\mu \mathrm{mol} \mathrm{m} \mathrm{m}^{-2} \mathrm{~s}^{-1}$ ) with the application of $15.52 \mathrm{~mL} \mathrm{~L}^{-1}$ of Si (Figure $2 \mathrm{~B})$. At $60 \mathrm{DAl}$, the beet plants showed an increase as the 
Si doses increased, with the highest net photosynthetic rate $\left(19 \mu \mathrm{mol} \mathrm{m} \mathrm{m}^{-2} \mathrm{~s}^{-1}\right)$ with the application of $15.52 \mathrm{~mL} \mathrm{~L}^{-1}$ (Figure 3B). Jesus et al. (2018) also found that the rate of net photosynthesis increased with the foliar application of silicon in arugula, corroborating the results obtained in the present study.

The increase in the net photosynthetic rate can be attributed to the beneficial effects of Si, among them, the formation of a physical layer on the leaves, promoting a reduction in transpiration, which may have facilitated the opening of the stomata of beet plants (Heckman, 2013; Cantuário et al., 2014), promoting a higher photosynthetic rate of these plants.

In other studies it was also observed that $\mathrm{Si}$ promotes an increase in photosynthetic activity and growth of many species of plants (canola, soybeans,
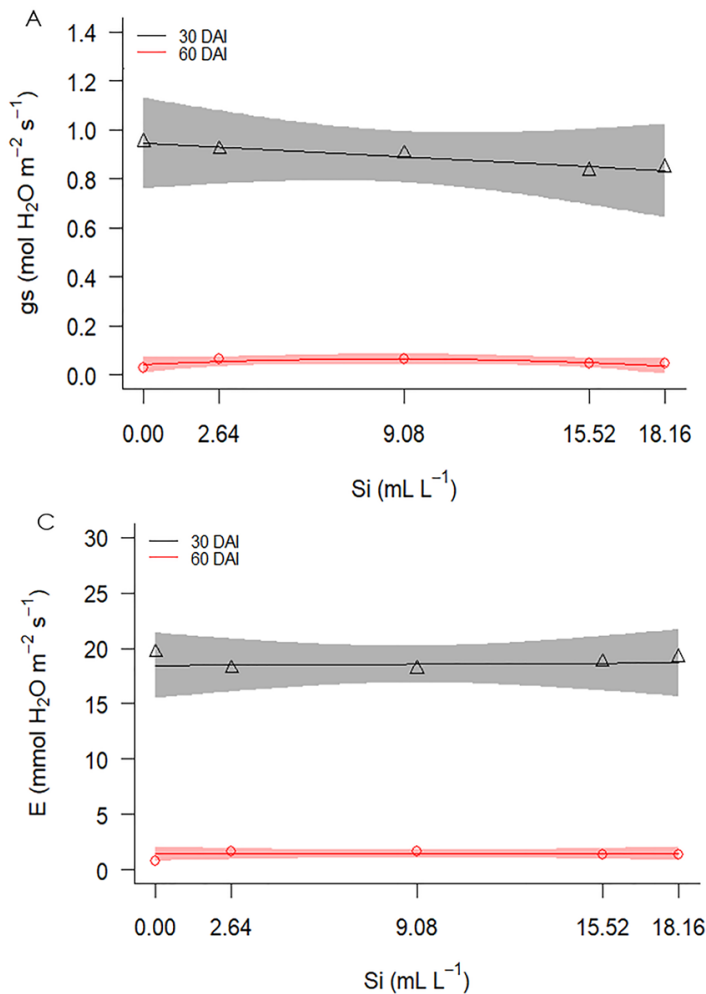

Figure 3. Stomatal conductance ( $g$ - A), net photosynthesis (A - B), transpiration (E - C) and internal carbon concentration (Ci - D) of beet plants at 30 and 60 days after application (DAI) of silicon.

However, the reductions observed in the internal carbon concentration are due to decreases in the rate of $\mathrm{CO}_{2}$ dioxide assimilation, which can be attributed to the fact that during gas exchanges, the absorption of $\mathrm{CO}_{2}$ coincides with the loss of water and, conversely, the reduction of this loss limits the assimilation of $\mathrm{CO}_{2}$ and, consequently, less internal concentration of $\mathrm{CO}_{2}$ occurs (Shimazaki et al., 2007).

The intrinsic efficiency of carboxylation (iCE), water use efficiency (WUE) and instantaneous water use efficiency (iWUE) showed differences in both evaluation wheat, sorghum, tomatoes and corn) submitted to salt stress conditions, which had a larger leaf area, the chlorophyll content and improved the structure of chloroplasts (Tahir et al., 2012; Bae et al., 2012; Yin et al., 2013; Haghighi \& Pessarakli, 2013; Rohanipoor et al., 2013).

At 30 and $60 \mathrm{DAl}$ it was observed that the internal $\mathrm{CO}_{2}$ concentration increased up to the dose of $9.08 \mathrm{~mL} \mathrm{~L}^{-1}$, decreasing in subsequent doses, obtaining in this dose the highest internal CO2 concentrations $\left(140 \mu \mathrm{mol} \mathrm{m} \mathrm{m}^{-2} \mathrm{~s}^{-1}\right)$ and (105 $\left.\mu \mathrm{mol} \mathrm{m}^{-2} \mathrm{~s}^{-1}\right)$, respectively. The higher concentration of $\mathrm{CO}_{2}$ in the beet plants indicates low activity of the enzyme ribulose-1,5-bisphosphate carboxylaseoxygenase (Rubisco), however, in the present study the highest concentration of $\mathrm{CO}_{2}$ coincided with the highest photosynthetic activity, which may have been a high activity of Rubisco (Silva et al., 2011).
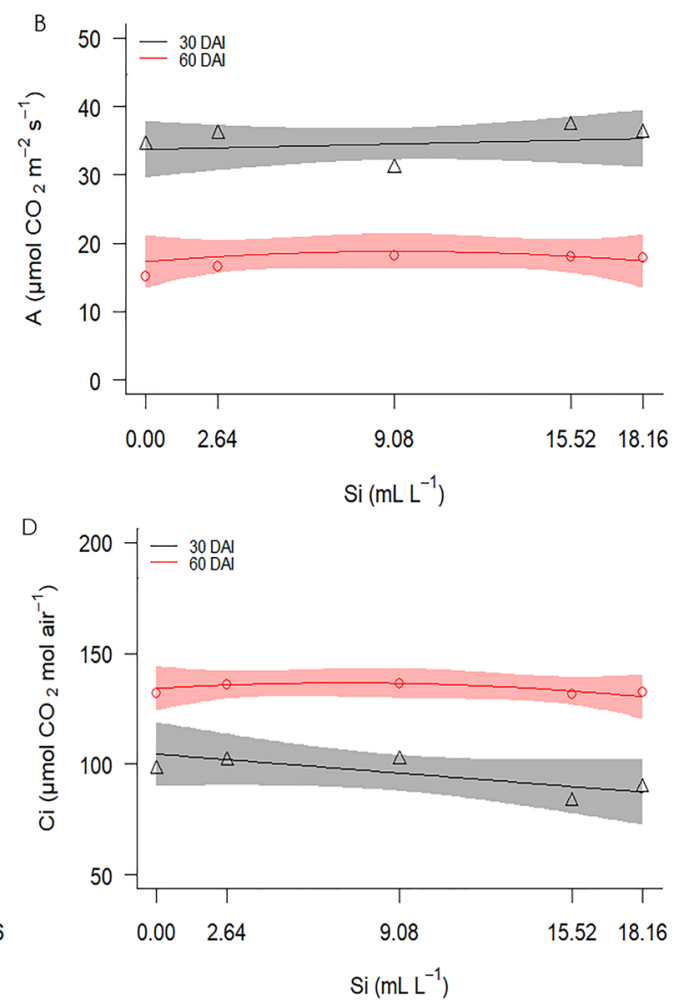

periods in relation to ECW. For iCE, WUE and iWUE, there was a difference in all the ECWs in relation to the evaluation period. For the WUE and iWUE the highest averages were observed at $60 \mathrm{DAl}$, the opposite being the case for iCE.

The intrinsic efficiency of carboxylation, at $60 \mathrm{DAl}$, decreased as the levels of ECW increased, obtaining the highest value in beet plants irrigated with water of $0.5 \mathrm{dS}$ $\mathrm{m}^{-1}$, and the smallest with $1.23 \mathrm{dS} \mathrm{m}^{-1}$ water irrigation. At $30 \mathrm{DAl}$, the intrinsic efficiency of the carboxylation of beet plants oscillated (Figure 4A). 

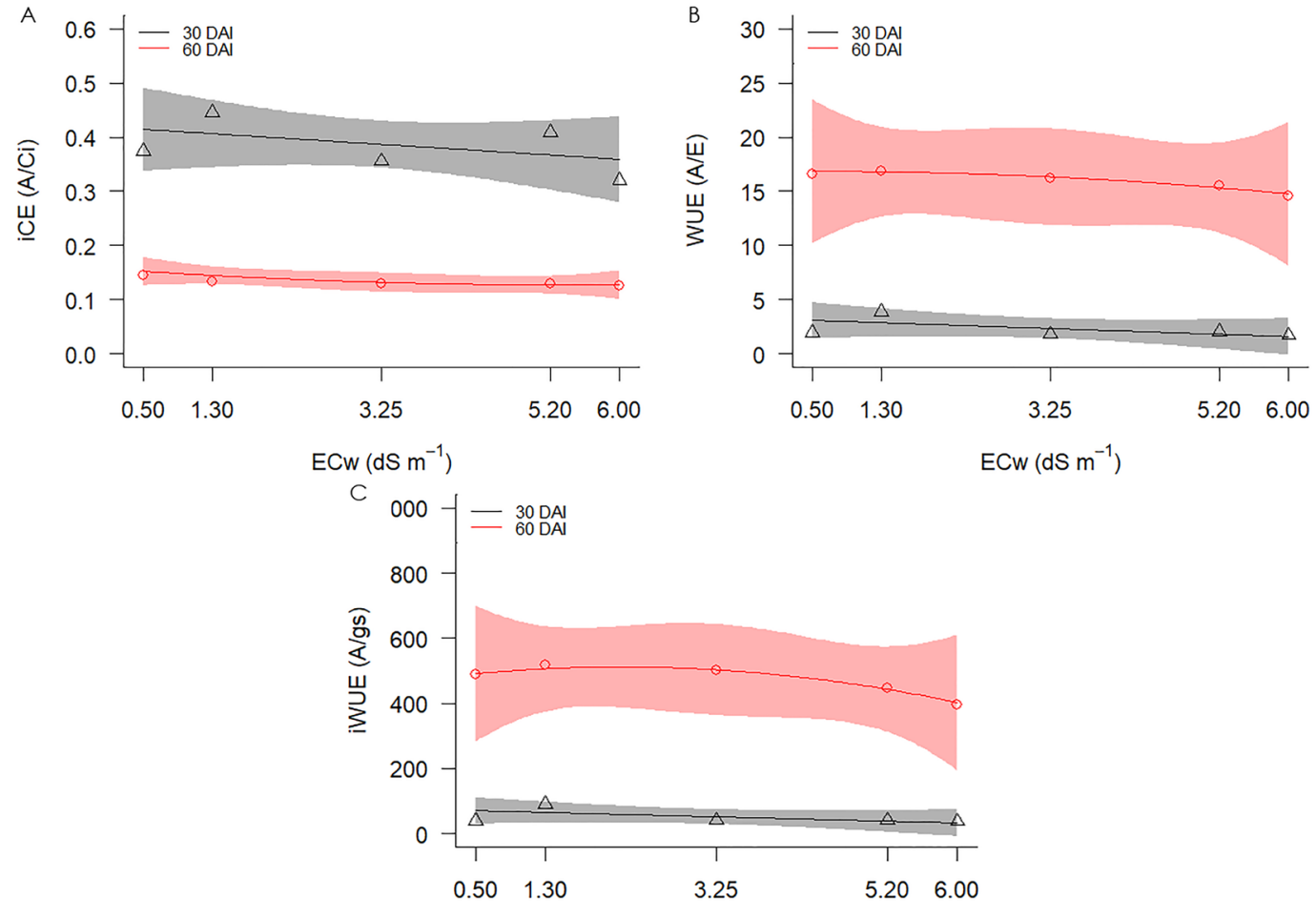

$\mathrm{ECW}\left(\mathrm{d} S \mathrm{~m}^{-1}\right)$

Figure 4. Intrinsic carboxylation efficiency (iCE - A), water use efficiency (WUE - B) and instantaneous water use efficiency (iWUE - C) of beet plants at 30 and 60 days after the start of irrigation (DAI) with saline water.
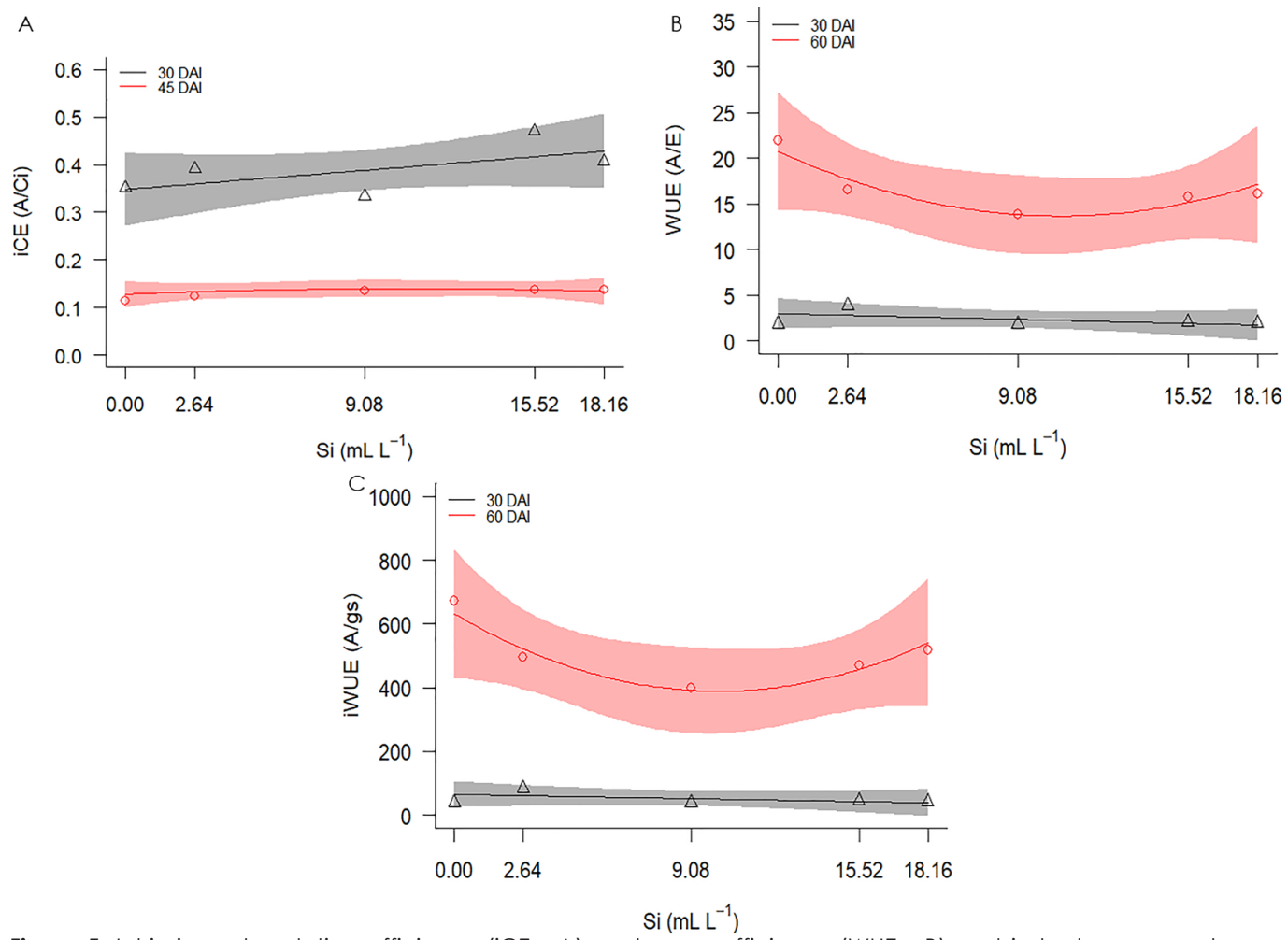

Figure 5. Intrinsic carboxylation efficiency (iCE - A), water use efficiency (WUE - B) and instantaneous water use efficiency (iWUE - C) of beet plants submitted to silicon application (Si) at 30 and 60 days after the beginning of irrigation (DAl) with saline water.

The increase in ECW levels reduced the water use efficiency of beet plants, presenting the highest value in plants irrigated with water of $0.50 \mathrm{dS} \mathrm{m}^{-1}$, at $60 \mathrm{DAl}$ the lowest value under irrigation with water of $3.25 \mathrm{dS} \mathrm{m}^{-1}$
(Figure 4B).

As for the application of $\mathrm{Si}$, there was a difference between the evaluation periods for the iCE, WUE and IWUE. As for the behavior in relation to the 
evaluation period, WUE and iWUE had higher averages at $60 \mathrm{DAl}$, while the iCE was at $30 \mathrm{DAl}$. It was noted that in all variables, except for iCE, the application of Si up to the dose of $9.08 \mathrm{~mL} \mathrm{~L}^{-1}$ showed a decrease, increasing in subsequent doses. The opposite was observed for iCE. These results corroborate those observed by Jesus et al. (2018) in arugula, when they found that the application of silicon reduced the efficiency in the use of water.

\section{Conclusions}

Irrigation with saline water reduced the gas exchange of beet plants at 60 days after irrigation, but at 30 days after irrigation, the use of saline water increased stomatal conductance, transpiration rate and internal carbon concentration.

The application of silicon decreased stomata conductance, internal carbon concentration and efficiency in the use of water, but increased the rate of net photosynthesis, the rate of transpiration and instantaneous efficiency of carboxylation at 30 and 60 days after irrigation.

\section{References}

Ali, A., Basra, S.M., Hussain, S., labal, J. 2012. Increased growth and changes in wheat mineral composition through calcium silicate fertilization under normal and saline field conditions. Chilean Journal of Agricultural Research 72: 98-103.

Bae, E.J., Lee, K.S., Huh, M.R., Lim, C.S. 2012. Silicon significantly alleviates the growth inhibitory effects of $\mathrm{NaCl}$ in salt-sensitive 'Perfection' and 'Midnight'Kentucky bluegrass (Poa pratensis L.). Horticulture, Environment, and Biotechnology 53: 477-483.

Cantuário, F.S., Luz, J.M.Q., Pereira, A.I.A., Salomão, L.C., Rebouças, T.N.H. 2014. Podridão apical e escaldadura em frutos de pimentão submetidos a estresse hídrico e doses de silício. Horticultura Brasileira 32: 215-219.

Cerqueira, R.C., Costa, J.M., Chaves, M.M., Rodrigues, J.D. 2015. Fisiologia e metabolismo foliar em duas variedades de videira sujeitas a um ciclo de défice hídrico e reidratação. Revista Brasileira de Ciências Agrárias 10: 211-217.

Embrapa - Empresa Brasileira de Pesquisa Agropecuária. 2014. Sistema Brasileiro de Classificação de Solo. 4. ed. Embrapa Solos, Brasília, Brazil. 376 p.

Ferraz, R.L.D.S., Magalhães, I.D., Beltrão, N.E.D.M., Melo, A.S.D., Neto, B., Rocha, M.D.S. 2015. Photosynthetic pigments, cell extrusion and relative leaf water content of the castor bean under silicon and salinity. Revista Brasileira de Engenharia Agrícola e Ambiental 19: 841-848.

Ferraz, R.L.S., Beltrão, N.E.M., Melo, A.S., Magalhães, I.D., Dantas Fernandes, P. Rocha, M.S. 2014. Trocas gasosas e eficiência fotoquímica de cultivares de algodoeiro herbáceo sob aplicação de silício foliar. Semina: Ciências Agrárias 35: 735-748.

Filgueira, F.A.R. 2008. Novo manual de olericultura: Agrotecnologia moderna na produção e comercialização de hortaliças. 2.ed. UFV, Viçosa, Brazil. $412 \mathrm{p}$.

Freire, J.L.O., Dias, T.J., Cavalcante, L.F., Fernandes, P.D., Lima Neto, A.J. 2014. Rendimento quântico e trocas gasosas em maracujazeiro amarelo sob salinidade hídrica, biofertilização e cobertura morta. Revista Ciência Agronômica 45: 82-91.

Ghobadi, M., Taherabadi, S., Ghobadi, M.E., Mohammadi, G.R., Jalali-Honarmand, S. 2013. Antioxidant capacity, photosynthetic characteristics and water relations of sunflower (Helianthus annuus L.) cultivars in response to drought stress. Industrial Crops and Products 50: 29-38.

Guntzer, F., Keller, C., Meunier, J.D. 2012. Benefits of plant silicon for crops: a review. Agronomy for Sustainable Development 32: 201-213.

Haghighi, M., Pessarakli, M. 2013. Influence of silicon and nano-silicon on salinity tolerance of cherrytomatoes (Solanum lycopersicum L.) at early growth stage. Scientia Horticulturae 161:111-117.

Heckman, B.J. 2013. Silicon: A Beneficial Substance. Better Crops 97: 14-16.

IPA - Instituto Agronômico de Pernambuco. 2008. Recomendação de adubação para o Estado de Pernambuco: $2^{\circ}$ aproximação. 3.ed. Instituto Agronômico de Pernambuco, Recife, Brazil. 212 p.

Jesus, E.G.D., Fatima, R.T.D., Guerrero, A.C, Araújo, J.L.D., Brito, M.E. 2018. Growth and gas exchanges of arugula plants under silicon fertilization and water restriction. Revista Brasileira de Engenharia Agrícola e Ambiental 22: 119-124.

Kusvuran, S. 2012. Effects of drought and salt stresses on growth, stomatal conductance, leaf water and osmotic potentials of melon genotypes (Cucumis melo L.). African Journal Agricultural Research 7: 2012.

Luz, J.M.Q., Guimarães, S.T.M.R., Korndörfer, G. H. 2006. Produção hidropônica de alface em solução nutritiva com e sem silício. Horticultura Brasileira 24: 295-300.

Mateus, N.B., Barbin, D., Conagin, A. 2001. Viabilidade de uso do delineamento composto central. Acta Scientiarum 23: 1537-1546.

Medeiros, J.F. 1992. Qualidade da água de irrigação e evolução da salinidade nas propriedades assistidas pelo "GAT" nos Estados do RN, PB e CE. 173p. (Dissertation) Federal University of Paraiba, Campina Grande, Brazil.

Munns, R., Tester, M. 2008. Mechanisms of salinity tolerance. Annual Review of Plant Biology 59: 51-81.

Oliveira, F.I.F., Souto, A.G.L., Cavalcante, L.F., Medeiros, W.J.F., Bezerra, F.T.C., Bezerra, M.A.F. 2017. Quality of jackfruit seedlings under saline water stress and nitrogen 
fertilization. Semina: Ciências Agrárias 38: 2337-2350.

Pereira, T.S., Lobato, A.K.S., Tan, D.K.Y. 2013. Positive interference of silicon on water relations, nitrogen metabolism, and osmotic adjustment in two pepper (Capsicum annuum) cultivars under water deficit. Australian Journal of Crop Science 7:1064-1071.

R Core Team. R: A language and environment for statistical computing. Vienna: R Foundation for Statistical Computing, 2018.

Richards, L.A. 1954. Diagnosis and improvement of saline and alkali soils. US Department of Agriculture, Washington, USA. $160 \mathrm{p}$.

Rohanipoor, A., Norouzi, M., Moezzi, A., Hassibi, P. 2013. Effect of silicon on some physiological properties of maize (Zea mays) under salt stress. Journal of Biodiversity and Environmental Sciences 7: 71-79.

Sá, F.V.S., Brito, M.E.R., Ferreira, I.B., Antônio Neto, P., Silva, L.A., Costa, F.B. 2015. Balanço de sais e crescimento inicial de mudas de pinheira (Annona squamosa L.) sob substratos irrigados com água salina. Irriga 20: 544-556.

Sá, F.V.S., Pereira, F.H.F., Lacerda, F.H.D., Silva, A.D. 2013. Crescimento inicial e acúmulo de massa seca de cultivares de mamoeiro submetidas à salinidade da água em cultivo hidropônico. Revista Brasileira de Ciências Agrárias 8: 435-440.

Sahebi, M., Hanafi, M.M., Azizi, P. 2016. Application of silicon in plant tissue culture. In Vitro Cellular and Developmental Biology-Plant 52: 226-232.

Shimazaki, K.I., Doi, M., Assmann, S.M., Kinoshita, T. 2007. Light regulation of stomatal movement. Annual Review of Plant Biology 58: 219-247.

Silva, E.N.D., Ribeiro, R.V., Ferreira-Silva, S.L., Viégas, R.A., Silveira, J.A.G. 2011. Salt stress induced damages on the photosynthesis of physic nut young plants. Scientia Agricola 68: 62-68.

Silva, T.G.F., Zolnier, S., Grossi, J.A.S., Barbosa, J.G., Moura, C.R.W., Muniz, M.A. 2009. Crescimento do girassol ornamental cultivado em ambiente protegido sob diferentes níveis de condutividade elétrica de fertirrigação. Revista Ceres 56:602-610.

Sousa, J.R.M., Gheyi, H.R., Brito, M.E.B., Xavier, D.A., Furtado, G.F. 2016. Impact of saline conditions and nitrogen fertilization on citrus production and gas exchanges. Revista Caatinga 29: 415-424.

Tahir, M.A., Aziz, T., Farooq, M., Sarwar, G. 2012. Siliconinduced changes in growth, ionic composition, water relations, chlorophyll contents and membrane permeability in two salt-stressed wheat genotypes. Archives of Agronomy and Soil Science 58: 247-56.

Taiz, L., Zeiger, E., Møller, I.M., Murphy, A. 2017. Fisiologia e desenvolvimento vegetal. 6.ed. Editora Artmed, Porto Alegre, Brazil. 858 p.

Yin, L., Wang, S., Li, J., Tanaka, K., Oka, M. 2013. Application of silicon improves salt tolerance through ameliorating osmotic and ionic stresses in the seedling of Sorghum bicolor. Acta Physiologiae Plantarum 35: 1-9.

Zhu, Y., Gong, H. 2014. Beneficial effects of silicon on salt and drought tolerance in plants. Agronomy for Sustainable Development 34: 455-472.

Conflict of Interest Statement: The authors declare that the research was conducted in the absence of any commercial or financial relationships that could be construed as a potential conflict of interest.

All the contents of this journal, except where otherwise noted, is licensed under a Creative Commons Attribution License attribuition-type BY. 